\title{
Hormonal, global, and regional haemodynamic responses to a vascular antagonist of vasopressin in patients with congestive heart failure with and without hyponatraemia
}

\author{
P NICOD, J BIOLLAZ, B WAEBER, J J GOY, R POLIKAR, J SCHLAPFER, \\ M D SCHALLER, G A TURINI, J NUSSBERGER, K G HOFBAUER, \\ H R BRUNNER \\ From the Department of Medicine, Centre Hospitalier Universitaire, Lausanne, Switzerland
}

SUMMARY The pathophysiological role of an increase in circulating vasopressin in sustaining global and regional vasoconstriction in patients with congestive heart failure has not been established, particularly in patients with hyponatraemia. To assess this further, 20 patients with congestive heart failure refractory to digoxin and diuretics were studied before and 60 minutes after the intravenous injection $(5 \mu \mathrm{g} / \mathrm{kg})$ of the vascular antagonist of vasopressin [1 $(\beta$-mercapto- $\beta$, $\beta$-cyclopentamethylene-propionic acid), 2-(0-methyl) tyrosine] arginine vasopressin. Ten patients were hyponatraemic (plasma sodium $<135 \mathrm{mmol} / \mathrm{l}$ ) and 10 were normonatraemic. In both groups of patients the vascular vasopressin antagonist did not alter systemic or pulmonary artery pressures, right atrial pressure, pulmonary capillary wedge pressure, cardiac index, or vascular resistances. Furthermore, there was no change in skin and hepatic blood flow in either group after the injection of the vascular antagonist. Only one patient in the hyponatraemic group showed considerable haemodynamic improvement. He had severe congestive heart failure and a high concentration of plasma vasopressin $(51 \mathrm{pmol} / 1)$. Plasma renin activity, vasopressin, or catecholamine concentrations were not significantly changed in response to the administration of the vasopressin antagonist in either the hyponatraemic or the normonatraemic groups. Patients with hyponatraemia, however, had higher baseline plasma catecholamine concentrations, heart rate, pulmonary pressure and resistance, and lower hepatic blood flow than patients without hyponatraemia. Plasma vasopressin and plasma renin activity were slightly, though not significantly, higher in the hyponatraemic group. Thus the role of vasopressin in sustaining regional or global vasoconstriction seems limited in patients with congestive heart failure whether or not concomitant hyponatraemia is present. Vasopressin significantly increases the vascular tone only in rare patients with severe congestive heart failure and considerably increased vasopressin concentrations. Patients with hyponatraemia do, however, have raised baseline catecholamine concentrations, heart rate, pulmonary arterial pressure and resistance, and decreased hepatic blood flow.

Patients with congestive heart failure often show an activation of the sympathetic nervous system and the renin-angiotensin system and an increase in plasma vasopressin concentration. The resulting rise

Requests for reprints to Dr P Nicod, Cardiology Division H-811A, UCSD Medical Center, 225 Dickinson Street, San Diego, California 92103, USA.

Accepted for publication 8 July 1986 in systemic vascular resistance and heart rate and alteration of regional blood flow may be viewed as an adaptative mechanism to a low cardiac output and also as a factor sustaining the congestive state. Although the sympathetic system ${ }^{1-3}$ and the reninangiotensin system ${ }^{4-6}$ produce considerable haemodynamic changes during congestive heart failure, the role of vasopressin is less clear. Plasma vasopressin concentrations were raised in patients with 
Table 1 Clinical characteristics of study groups

\begin{tabular}{|c|c|c|c|c|c|c|c|}
\hline Patients & $\begin{array}{l}\text { Age } \\
\text { (years) } \\
\text { (SD) }\end{array}$ & Sex & Diagnosis & Diuretics & Digoxin & $\begin{array}{l}\text { Other } \\
\text { medications }\end{array}$ & $\begin{array}{l}\text { Mean fractional } \\
\text { shortening by } \\
\text { echocardiography } \\
\text { (1 SEM) }\end{array}$ \\
\hline With hyponatraemia & $64(19)$ & $\begin{array}{l}8 \mathrm{M} \\
2 \mathrm{~F}\end{array}$ & $\begin{array}{l}6 \text { IDC } \\
4 \text { CAD }\end{array}$ & $\begin{array}{l}4 \text { frusemide } \\
1 \text { thiazide } \\
1 \text { thiazide }+ \text { spironolactone } \\
1 \text { thiazide + amiloride }\end{array}$ & 10 & 1 quinidine & $0.14(0.01)$ \\
\hline Without hyponatraemia & $51(15)$ & $\begin{array}{l}9 \mathrm{M} \\
1 \mathrm{~F}\end{array}$ & $\begin{array}{l}8 \mathrm{IDC} \\
1 \mathrm{CAD} \\
1 \mathrm{LVR}\end{array}$ & $\begin{array}{l}2 \text { frusemide } \\
2 \text { thiazide } \\
2 \text { frusemide }+ \text { spironolactone } \\
2 \text { thiazide }+ \text { amiloride }\end{array}$ & 10 & $\begin{array}{l}1 \text { amiodarone } \\
1 \text { allopurinol } \\
1 \text { mexiletine }\end{array}$ & $0.13(0.01)$ \\
\hline
\end{tabular}



congestive heart failure in several studies. ${ }^{7-9}$ In a preliminary report we have shown that vasopressin may have some global vasoconstrictive activity in rare patients presenting with pronounced haemodynamic instability. ${ }^{9}$ Little is known, however, about the influence of vasopressin on regional redistribution of blood flow in patients with congestive heart failure. Furthermore, the pathophysiological role of vasopressin in patients with hyponatraemia compared with its role in those without hyponatraemia is unknown. Although similar plasma concentrations of vasopressin have been described in patients with congestive heart failure with and without hyponatraemia, vasopressin concentrations are inappropriately high in the context of plasma sodium concentration, especially in patients with hyponatraemia.

We have analysed the global and the regional haemodynamic variables before and after the injection of a vascular antagonist of vasopressin in patients with congestive heart failure and we have compared the results obtained in patients with hyponatraemia with those obtained in patients without hyponatraemia.

\section{Patients and methods}

\section{PATIENT SELECTION}

Twenty patients were studied $(17$ men and 3 women, aged 19 to 81) with New York Heart Association class III and IV congestive heart failure refractory to conventional treatment with digoxin and diuretics. Patients were divided into two groups according to plasma sodium concentration. One group (10 patients) was hyponatraemic (plasma sodium < $135 \mathrm{mmol} / 1$ (mean (SEM) 129 (2) mmol/l) and the other group (10 patients) was normonatraemic (plasma sodium 137 (1) $\mathrm{mmol} / \mathrm{l}$ ). Table 1 shows their clinical characteristics and their medications. At the time of the study all patients had been maintained on stable doses of digoxin and diuretics for at least two weeks. They had been on a daily diet of $<3 \mathrm{~g}$ sodium for at least three days. The aetiology of congestive heart failure was idiopathic dilated cardiomyopathy in 14 patients, coronary artery disease in five patients, and late valvar replacement for aortic insufficiency in one patient. All reported symptoms of congestive heart failure for at least three months before the study. Any vasodilator treatment, mostly nitrates, was discontinued at least two days before the study. No patient had been on angiotensin converting enzyme inhibitors. To be included in the study all patients had to be free of unstable angina or recent myocardial infarction.

\section{HAEMODYNAMIC MEASUREMENTS}

A triple lumen themodilution Swan-Ganz catheter was inserted through the right femoral vein to the pulmonary artery of each patient. An 18-20 gauge catheter was then introduced into the right femoral artery. Both catheters were connected to two transducers positioned at the height of the mid-chest. We measured systemic and pulmonary arterial pressures, pulmonary capillary wedge pressure, right atrial pressure, and cardiac output determined in duplicate by thermodilution. Pressures were continuously monitored by digital readout. Cardiac index was calculated by correction for body surface. Sytemic and pulmonary resistances were calculated according to a standard formula and expressed as dyn $\mathrm{cm}^{-5} \cdot{ }^{10}$

HEPATIC BLOOD FLOW

Hepatic blood flow was determined by the indocyanine green method ${ }^{1112}$ in 13 patients (seven in the hyponatraemic and six in the normonatraemic group). Indocyanine green for human use (Cardiogreen, Hynson Westcott and Dunning, Baltimore, Maryland) was injected as a bolus of $0.5 \mathrm{mg} / \mathrm{kg}$ over five seconds. The vein was then rinsed with $10 \mathrm{ml}$ of the solvent. Blood samples were withdrawn into Vacutainer tubes at $1,2,3,4,5,6,7,8,10,12,15$, 
Table 2 Hormonal values before and 60 minutes after the injection of the antagonist of vasopressin (mean (1SEM))

\begin{tabular}{|c|c|c|c|}
\hline Patients & With hyponatraemia & Without hyponatraemia & $p$ \\
\hline $\begin{array}{l}\text { Sodium }(\mathrm{mmol} / \mathrm{l}) \\
\text { Arginine vasopressin }(\mathrm{pmol} / \mathrm{l}) \\
\text { Plasma renin activity }(\mathrm{pmol} / \mathrm{l} / \mathrm{s}) \text { : }\end{array}$ & $\begin{array}{l}129(2) \\
\quad 7 \cdot 4(4 \cdot 9)\end{array}$ & $\begin{array}{l}137(1) \\
1.6(0.2)\end{array}$ & $\begin{array}{l}<0.01 \\
\text { NS }\end{array}$ \\
\hline $\begin{array}{l}\text { Before } \\
\text { After } \\
\text { p }\end{array}$ & $\begin{aligned} 1.5(0.4) \\
1.4(0.5) \\
\text { NS }\end{aligned}$ & $\begin{array}{l}0.6(0 \cdot 1) \\
0.5(0 \cdot 1) \\
\text { NS }\end{array}$ & NS \\
\hline Plasma adrenaline (nmol/1): & & & \\
\hline $\begin{array}{l}\text { Before } \\
\text { After } \\
\text { p }\end{array}$ & $\begin{array}{l}5.95(2 \cdot 46) \\
10 \cdot 43(6 \cdot 17) \\
\text { NS }\end{array}$ & $\begin{array}{l}1.69(1.04) \\
0.66(0.27) \\
\text { NS }\end{array}$ & $\begin{array}{l}<0.05 \\
-\end{array}$ \\
\hline $\begin{array}{l}\text { Plasma noradrenaline (nmol/1): } \\
\text { Before } \\
\text { After } \\
\text { p }\end{array}$ & $\begin{array}{l}11.35(4 \cdot 14) \\
15.66(7.09) \\
\text { NS }\end{array}$ & $\begin{array}{l}2.07(0.35) \\
1.89(0.35) \\
\text { NS }\end{array}$ & $\begin{array}{l}<0.01 \\
-\end{array}$ \\
\hline
\end{tabular}
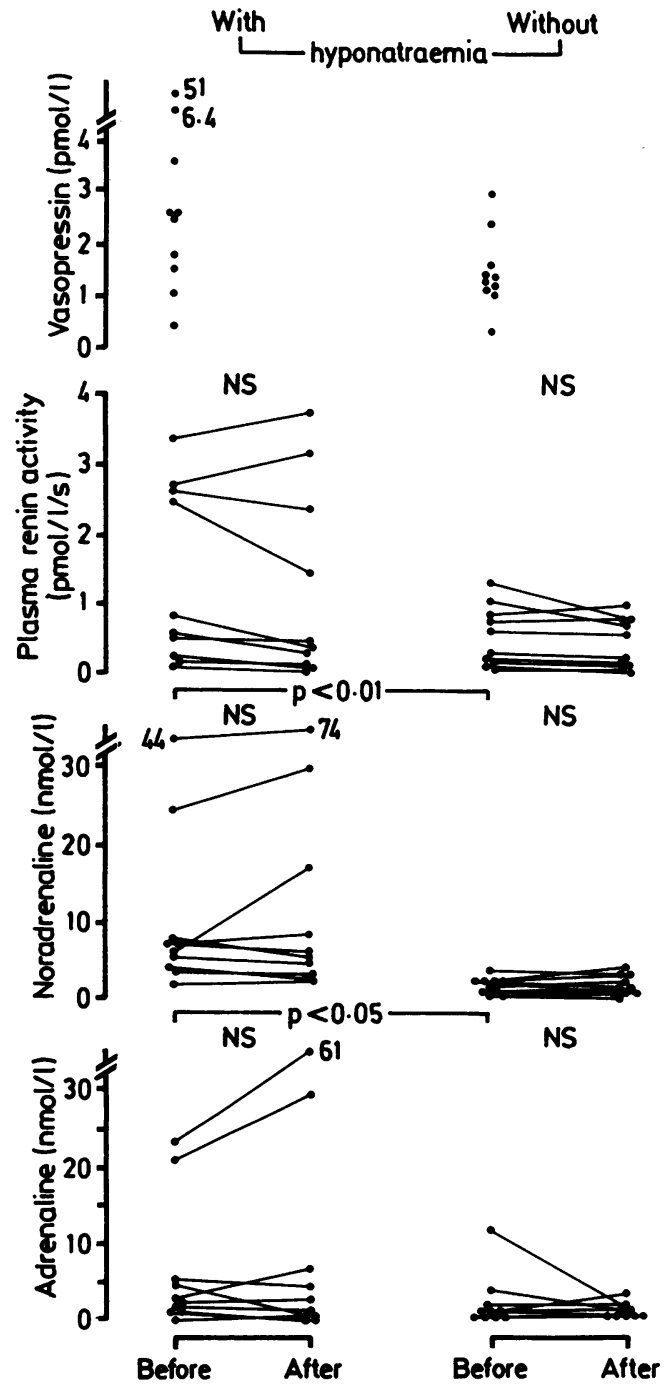

Fig 1 Hormonal values before and 60 minutes after the injection of the antagonist of vasopressin in patients with or without hyponatraemia. None of the hormones measured changed after the injection. Baseline values of noradrenaline and adrenaline were higher in the group with hyponatraemia. and 20 minutes. Plasma indocyanine green concentrations were measured immediately after centrifugation by spectrophotometry by means of Wickon 860 spectrophotometer (Kontron Instruments, Zurich, Switzerland) with absorbance set at $805 \mathrm{~nm}$. A standard calibration curve was prepared by adding indocyanine green (from the same solution as the one injected) to the subject's blank plasma.

The plasma clearance was measured from the slope (k) of the natural logarithm of plasma indocyanine green concentration against time divided by the extrapolated zero time concentration (Cpo) according to the equation:

$$
\text { Plasma clearance }=\frac{k \times \text { Dose }}{\text { Cpo }}
$$

Blood clearance was then obtained after correction for the measured hematocrit.

CUTANEOUS BLOOD FLOW

In all patients cutaneous blood flow was measured continuously by a probe applied to the left forearm. A laser Doppler flowmeter (Periflux, Perimed, Stockholm, Sweden) was used to determine skin blood flow. A laser beam emitted by the probe is reflected on the moving red cells of the skin capillaries. The output signal from the flowmeter is then related to the number of cells times their velocity and this is taken to represent the flux of red cells. Skin blood flow was expressed as a per cent of the arbitrarily preset maximal gain of the flowmeter and the tracings were recorded by a Sevogor 120 (BBC, Goez, Austria). This method of skin blood flow measurement has been described in detail elsewhere. ${ }^{13}$

HORMONAL MEASUREMENTS

Plasma renin activity ${ }^{14}$ and vasopressin ${ }^{15}$ were measured by radioimmunoassay. A radioenzymatic method was used to determine plasma catecholamines. ${ }^{16}$ Plasma osmolality was quantitated by an osmometer (Vogel, Giessen, West Germany).

\section{VASCULAR ANTAGONIST OF VASOPRESSIN}

The vasopressin antagonist used was [1 $(\beta$-mercapto- $\beta, \beta$-cyclopentamethylene propionic acid), 2-(0-methyl) tyrosine] arginine vasopressin 
(synthesised by Ciba Geigy, Basel, Switzerland). ${ }^{17}$ On the day of the study it was dissolved in $0.9 \%$ saline solution to a final concentration of $100 \mu \mathrm{g} / \mathrm{ml}$. This solution was passed through a Milex CS filter (Milipor, Molsheim, France) before intravenous injection.

\section{PROTOCOL}

After catheter insertion patients were kept at rest for at least one hour for complete haemodynamic stabilisation before any hormonal of haemodynamic measurement was performed. Two baseline values of pressures, cardiac output, and cutaneous blood flow were obtained 15 minutes apart. Hepatic blood flow was measured during the 15 minutes between measurements. The vasopressin antagonist was then given as a bolus intravenous injection at a dose of $5 \mu \mathrm{g} / \mathrm{kg}$. In an earlier study in normal volunteers given vasopressin this dose was shown to have a vascular effect for at least two hours. ${ }^{18}$ No agonist effect of the antagonist was detected in that study. Pres- sures and cutaneous blood flow were monitored continuously and recorded every 15 minutes for one hour. Cardiac output was measured at 30 to 60 minutes and hepatic blood flow at 60 minutes after the injection. Blood samples were drawn through the proximal lumen of the Swan-Ganz catheter immediately before and 60 minutes after the administration of the vasopressin antagonist.

\section{STATISTICAL ANALYSIS}

All data were expressed as mean (1 SEM). The statistical significance of the differences was evaluated by non-parametric methods, that is by the Wilcoxon sign rank test for paired data and by the MannWhitney test for unpaired data, with $p<0.05$ being taken as the minimum level of significance. ${ }^{19}$

\section{Results}

No patient reacted adversely to the administration of the vasopressin antagonist. Table 2 and fig 1 show hormonal values before and 60 minutes after the

Table 3 Global and regional haemodynamic variables before and 60 minutes after the injection of the antagonist of vasopressin (mean (1 SEM))

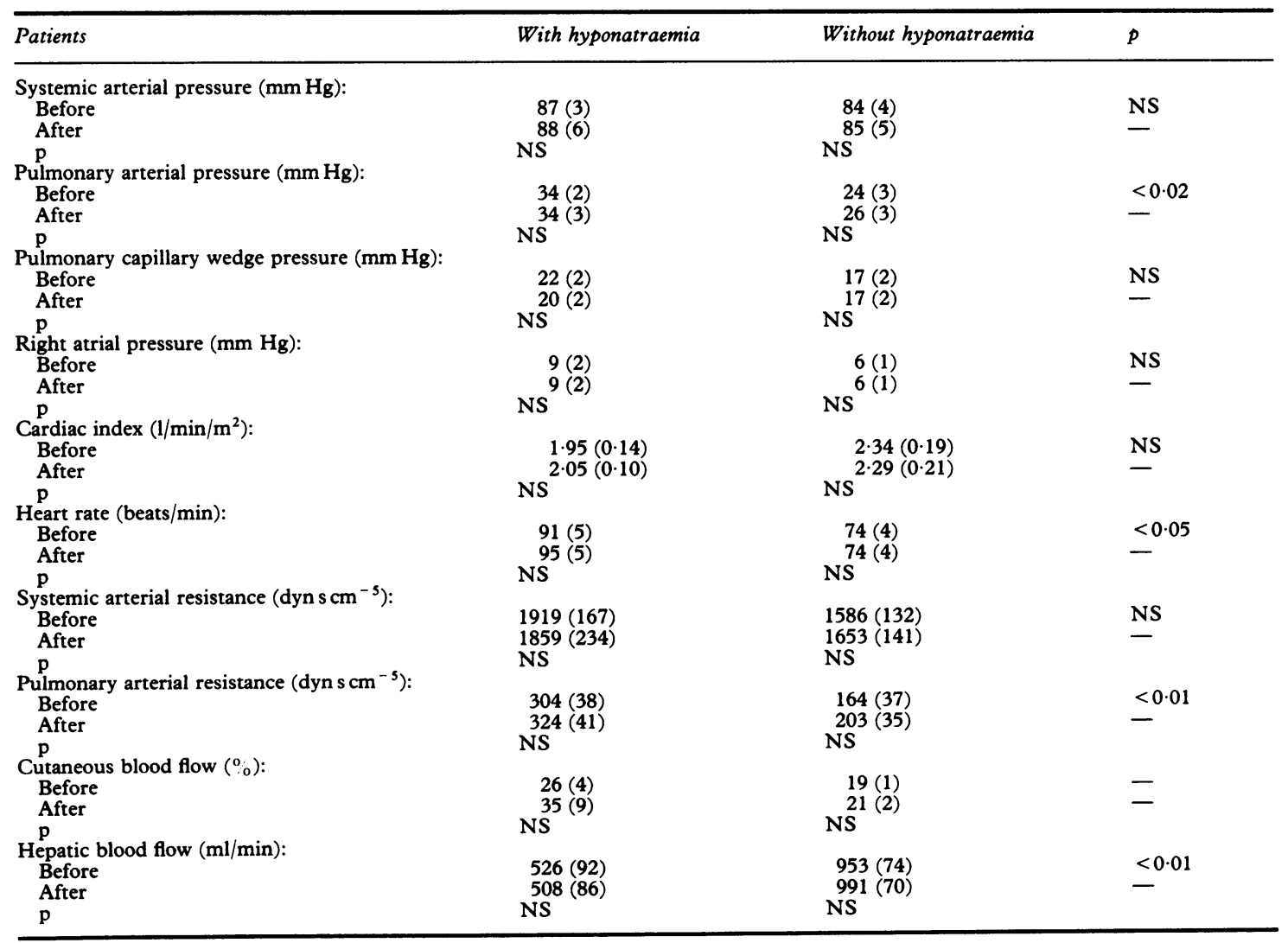




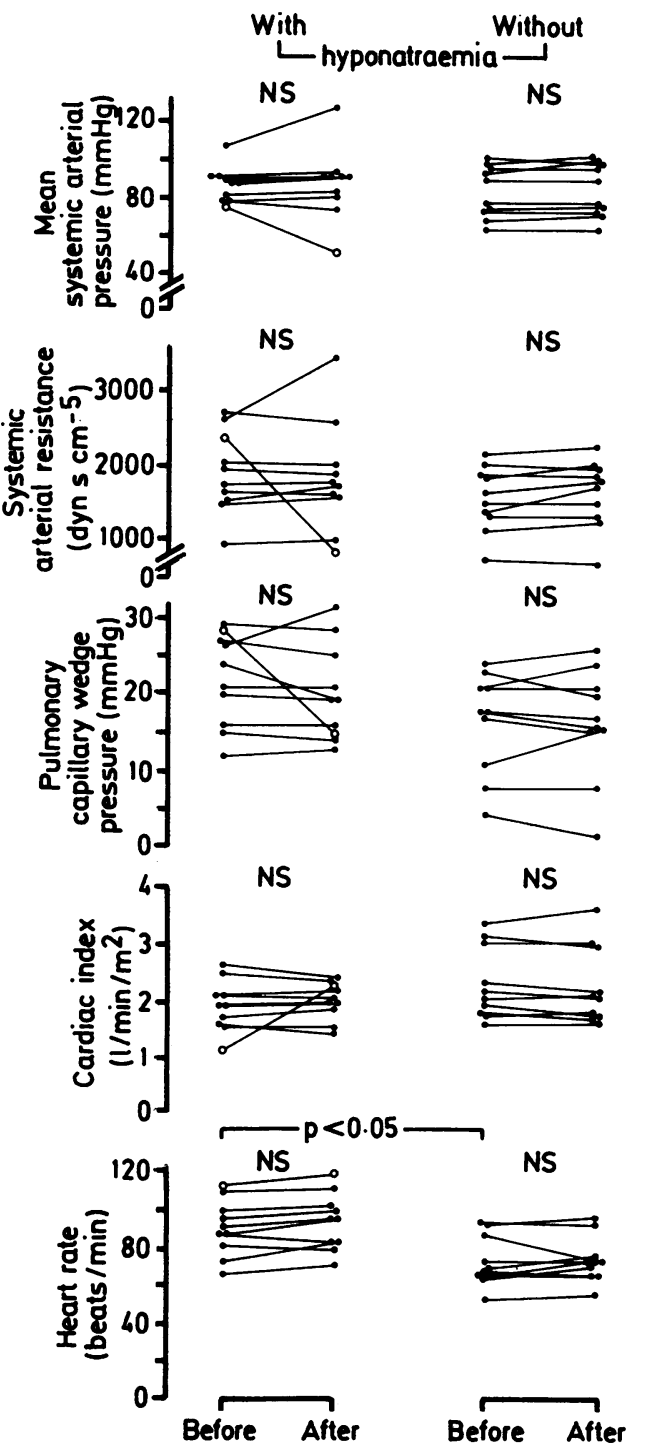

Fig 2 Global haemodynamic variables before and 60 minutes after the injection of the antagonist of vasopressin in patients with or without hyponatraemia. There was no significant change in either group after the injection. Only one patient (open circles) responded to the antagonist of vasopressin (see text). Baseline heart rate was significantly higher in the hyponatraemic group.

injection of the vasopressin antagonist in patients with and without hyponatraemia. None of the hormones changed significantly in response to the antagonist. After the administration of the vasopressin antagonist, vasopressin concentrations could not be measured because of a cross reaction of the

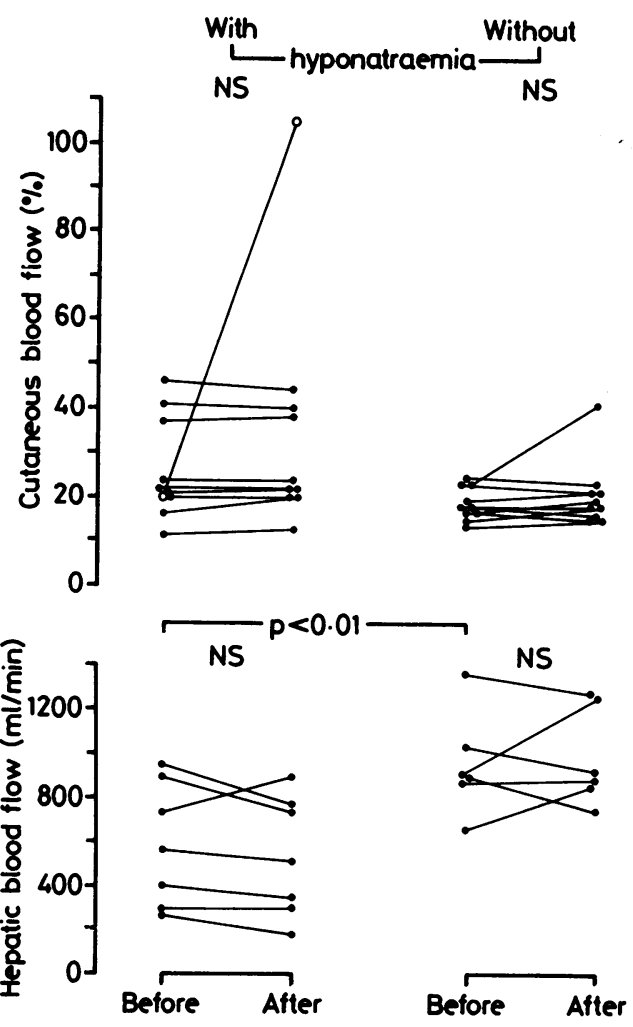

Fig 3 Regional haemodynamic variables before and 60 minutes after the injection of the antagonist of vasopressin in patients with or without hyponatraemia. No significant change was found after the injection in either group. Only one patient (open circles) showed a considerable increase in cutaneous blood flow (see text). Baseline hepatic blood flow was lower in the group with hyponatraemia.

antibody with the vasopressin antagonist in the assay. Baseline values, however, differed between the hyponatraemic and normonotraemic groups. Plasma renin activity and vasopressin concentrations tended to be higher, but not significantly, in the group with hyponatraemia. Concentrations of adrenaline $(5.95(2.46)$ vs $1.69(1.04) \mathrm{nmol} / \mathrm{l} ; \mathrm{p}<$ $0.05)$ and noradrenaline $(11.35(4.14)$ vs 2.07 $(0.35) \mathrm{nmol} / \mathrm{l} ; \mathrm{p}<0.01)$ were significantly higher in the hyponatraemic than in the normonatraemic group.

Table 3 summarises all haemodynamic values obtained before and 60 minutes after the injection of the vasopressin antagonist in both groups of patients. Figure 2 shows the responses of systemic arterial pressure, systemic arterial resistance, pulmonary capillary wedge pressure, cardiac index, and heart rate to the vasopressin antagonist. None of 
the haemodynamic variables measured changed significantly after the administration of the antagonist in either patients with or without hyponatraemia. Also there was no change in cutaneous or hepatic blood flow in either group of patients after the injection of the vascular antagonist (fig 3). Only one patient in the hyponatraemic group (shown in figs 2 and 3 as open circles) had dramatic haemodynamic changes, with a considerable decrease in pressures and systemic arterial resistance and increase in cardiac output and cutaneous blood flow. Hepatic blood flow was not measured in this patient. His plasma vasopressin concentration was $51 \mathrm{pmol} / \mathrm{l}$. This case was included in our previous report. ${ }^{9}$ Of the baseline haemodynamic values only heart rate (91 (5) vs 74 (4) beats/minute; $\mathrm{p}<0.05$ ), pulmonary arterial pressure (34 (3) vs 24 (3) $\mathrm{mm} \mathrm{Hg}, \mathrm{p}<0.02)$, and pulmonary arterial resistance (304 (38) vs 164 (37) dyn $\mathrm{cm}^{-5}, \mathrm{p}<0.01$ ) were significantly higher in the hyponatraemic group than in the normonatraemic group.

\section{Discussion}

VASCULAR EFFECT OF VASOPRESSIN IN PATIENTS WITH CONGESTIVE HEART FAILURE WITH AND WITHOUT HYPONATRAEMIA

The pathophysiological role of vasopressin in sustaining global vasoconstriction seems very limited in patients with New York Heart Association class III and IV congestive heart failure whether or not concomitant hyponatraemia is present. Indeed, most of our patients, both those who were hyponatraemic and those who were not with moderate increase in plasma vasopressin concentrations, did not show any global haemodynamic response to a specific vascular antagonist of vasopressin. Only one patient, described previously, ${ }^{9}$ showed a pronounced haemodynamic improvement. He had very severe congestive heart failure and died a few hours later of ventricular fibrillation. His was the only vasopressin concentration that was considerably raised (51 pmol/1). Similarly, a moderate increase in plasma vasopressin, which is often seen in patients with congestive heart failure, does not seen to affect blood flow redistribution significantly, since neither hepatic nor cutaneous blood flow increased after the administration of the vasopressin antagonist in either group. Again, only the patient with the vasopressin level of $51 \mathrm{pmol} / \mathrm{l}$ showed a pronounced increase in cutaneous blood flow. Thus the markedly raised plasma vasopressin concentrations that are seen only in rare patients with severe congestive heart failure do seem to affect global and regional vasoconstriction.

Because we studied short term administration of the vascular antagonist of vasopressin we cannot exclude the possibility of a more significant haemodynamic effect of long term administration, although this seems unlikely.

\section{HYPONATRAEMIA AND CONGESTIVE HEART FAILURE}

Hyponatraemia is common in patients with severe congestive heart failure. It has been attributed to several factors: (a) raised concentrations of vasopressin ${ }^{7-9}$; (b) a stimulation of the renin angiotensin system 2021 ; raised angiotensin concentrations leading to hyponatraemia through an impairment of free water clearance caused by a stimulation of vasopressin release, ${ }^{22}$ through some intrarenal blood flow redistribution, ${ }^{23}$ or stimulation of thirst $^{24}$; (c) intrarenal factors ${ }^{25}$; and (d) diuretic treatment and volume depletion. ${ }^{2126}$

In previous studies no significant differences in vasopressin concentrations were reported between patients with congestive heart failure with and without hyponatraemia. ${ }^{78} \mathrm{We}$ too found no differences in plasma concentrations nor in global or regional vasoconstrictive activity of vasopressin between these two groups of patients.

In our study plasma renin activity was slightly but not significantly higher in patients with congestive heart failure and hyponatraemia than in those without hyponatraemia. These findings, together with the significant increase in plasma renin activity seen in patients with hyponatraemia in other studies, ${ }^{20} 21$ can be interpreted in two ways. Firstly, our groups of patients were small, which raises the possibility that this was a coincidental observation. Secondly, most of our patients were still on diuretics at the time of the study; these can stimulate renin release and thus reduce any pre-existing difference between the two groups.

We cannot rule out the possibility that diuretics may be at least partly responsible for the development of hyponatraemia in our patients. In other studies diuretics were shown to produce hyponatraemia in patients with congestive heart failure. ${ }^{2126}$ We believe, however, that in our study diuretics were not a major factor contributing to the development of hyponatraemia. Indeed, hyponatraemic patients did not receive more diuretics than normonatraemic patients. Furthermore, filling pressures were raised to similar extents in the two groups, which rules out any important volume depletion in the hyponatraemic group. Finally, there were some clear cut differences between the two groups in catecholamine concentrations, hepatic blood flow, heart rate, pulmonary arterial pressure and resistance that are unlikely to be due to diuretic treatment and volume depletion alone. Patients with 
hyponatraemia had raised catecholamine concentrations, heart rate, pulmonary arterial pressure and resistance, and decreased hepatic blood flow, but there were no differences in the other haemodynamic variables measured. This pattern resembles results reported by Lilly et al in patients off diuretics, ${ }^{27}$ and probably reflects a more severe congestive heart failure in the hyponatraemic group. In the hyponatraemic group catecholamines may maintain global haemodynamic variables at values similar to the normonatraemic group by using the chronotropic and inotropic reserve of the heart.

In conclusion, plasma vasopressin seems to play a very limited role in sustaining global and regional vasoconstriction in patients with congestive heart failure with or without hyponatraemia. Hyponatraemia was not consistently associated with high plasma vasopressin concentrations nor with an increased haemodynamic response to the vasopressin antagonist. Hyponatraemia was, however, accompanied by increased catecholamine levels, heart rate, pulmonary arterial pressure and resistance, and decreased hepatic blood flow. This suggests that continuing hyponatraemia despite treatment with diuretics and digoxin is a marker for severe congestive heart failure.

This work was supported by grants from the Swiss National Foundation and from the Cardiovascular Research Foundation.

\section{References}

1 Chidsey CA, Braunwald E, Morrow AG. Catecholamine excretion and cardiac stores of norepinephrine in congestive heart failure. $\mathrm{Am}$ ₹ Med 1965;39:442-50.

2 Kramer RS, Mason DT, Braunwald E. Augmented sympathetic neurotransmitter activity in the peripheral vascular bed of patients with congestive heart failure and cardiac norepinephrine depletion. Circulation 1968;38:629-34.

3 Awan NA, Miller RR, Miller MP, Specht K, Vera Z, Mason DT. Clinical pharmacology and therapeutic application of prazosin in acute and chronic refractory congestive heart failure. Am $\mathcal{F}$ Med 1978;65:146-54.

4 Turini GA, Brunner HR, Ferguson RK, Rivier JL, Gavras H. Congestive heart failure in normotensive man: haemodynamics, renin, and angiotensin II blockade. $\mathrm{Br}$ Heart $\mathcal{f}$ 1978;40:1134-42.

5 Curtiss C, Cohn JN, Vrobel TR, Franciosa JA. Role of the renin-angiotensin system in the systemic vasoconstriction of chronic congestive heart failure. Circulation 1978;58:763-70.

6 Levine TB, Francis GS, Goldsmith SR, Simon RB, Cohn JN. Activity of the sympathetic nervous system and reninangiotensin system assessed by plasma hormone levels and their relation to haemodynamic abnormalities in congestive heart failure. $A m$ f Cardiol 1982;49:1659-66.

7 Szatalowics VL, Arnold PE, Chaimovitz C, Bichet D, Berl T, Schrier RW. Radioimmunoassay of plasma arginine vasopressin in hyponatremic patients with congestive heart failure. N Engl f Med 1981;305:263-6.
8 Goldsmith SR, Francis GS, Cowley AW, Levine TB, Cohn JN. Increased plasma arginine vasopressin levels in patients with congestive heart failure. $\mathcal{f} \mathrm{Am}$ Coll Cardiol 1983;1:1385-90.

9 Nicod P, Waeber B, Bussien JP, et al. Acute hemodynamic effect of a vascular antagonist of vasopressin in patients with congestive heart failure. Am $\mathcal{f}$ Cardiol 1985;55:1043-1047.

10 Grossman W, McLaurin LP. Clinical measurement of vascular resistance and assessment of vasodilator therapy. In: Grossman W, ed. Cardiac catheterization and angiography. Philadelphia: Lea and Febiger, 1980:116-23.

11 Caesar J, Shaldon S, Chiandussi L, Guevara L, Sherlock S. The use of indocyanine green in the measurement of hepatic blood flow and as a test of hepatic function. Clin $\mathrm{Sci}$ 1961;21:43-57.

12 Grainger SL, Kefling PWN, Brown IMH, Marigold JH, Thompson RPH. Clearance and non-invasive determination of the hepatic extraction of indocyanine green in baboons and man. Clin Sci 1983;64:207-12.

13 Nilson GE, Tenland T, Oberg PA. Evaluation of a laser Doppler flowmeter for measurement of tissue blood flow. IEEE Trans Biomed Eng 1980;27:597-604.

14 Nussberger J, Fasanella d'Amore T, Porchet M, Waeber B, Brunner DB, Brunner HR. Repeated administration of the converting enzyme inhibitor cilazapril to normal volunteers. $\mathcal{f}$ Cardiovasc Pharmacol (in press).

15 Brunner DB, Burnier M, Brunner HR. Plasma vasopressin in rats: effects of sodium, angiotensin, and catecholamines. $\mathrm{Am} \mathcal{F}$ Physiol 1983;244:H259-65.

16 Peuler JD, Johnson GA. Simultaneous single isotope radioenzymatic assay of plasma norepinephrine, epinephrine and dopamine. Life Sci 1977;21:625-36.

17 Kruszynski $M$, Lammer $B$, Manning $M$. [1- $\beta$-mercapto- $\beta$, $\beta$-cyclopentamethylenepropionic acid), 2 -(0-methyl)] tyrosine arginine vasopressin and $[1-(\beta$-mercapto- $\beta$, $\beta$-cyclopentamethylenepropionic acid)] arginine vasopressin, two highly potent antagonists of the vasopressor response to arginine-vasopressin. f Med Chem 1980;23:364-8.

18 Bussien JP, Waeber B, Nussberger J, et al. Does vasopressin sustain blood pressure of normally hydrated healthy volunteers? Am f Physiol 1984;246:H143-7.

19 Zar JH. Biostatistical analysis. Englewood Cliffs, NJ: Prentice Hall, 1974.

20 Levine TB, Franciosa JA, Vrobel T, Cohn JN. Hyponatraemia as a marker for high renin heart failure. $\mathrm{Br}$ Heart $\mathcal{f}$ 1982;47:161-6.

21 Schaer GL, Covit AB, Laragh JH, Cody RJ. Association of hyponatremia with increased renin activity in chronic congestive heart failure: impact of diuretic therapy. $\mathrm{Am} \mathcal{f} \mathrm{Cardiol}$ 1983;51:1635-8.

22 Bonjour JP, Malvin RL. Stimulation of ADH release by the renin-angiotensin system. Am $\mathcal{F}$ Physiol 1970;218:1555-9.

23 Hollenberg MK, Williams GH, Burger B, Ihikawa I, Adams DF. Blockade and stimulation of renal, adrenal and vascular angiotensin II receptors with 1-Sar, 8-Ala angiotensin II in normal man. $f$ Clin Invest 1976;57:39-46.

24 Johnson AK, Mann JF, Rasher W, Johnson JK, Ganten D. Plasma angiotensin II concentrations and experimentally induced thirst. Am $\mathcal{F}$ Physiol 1981;240:R229-34.

25 Schrier RW, Berl T. Nonosmolar factors affecting renal water excretion. $N$ Engl f Med 1975;292:81-8 and 141-5.

26 Fichman MP, Vorherr H, Kleeman CR, Telfer M. Diureticinduced hyponatremia. Ann Intern Med 1971;75:853-63.

27 Lilly LS, Dzau VJ, Williams GH, Rydstedt L, Hollenberg NK. Hyponatremia in congestive heart failure: implications for neurohumoral activation and responses to orthostatis. $\mathcal{f} \mathrm{Clin}$ Endocrinol Metab 1984;59:924-30. 